\title{
Differential regulation of vitamin D receptor expression in distinct leukemic cell lines upon phorbol ester-induced growth arrest
}

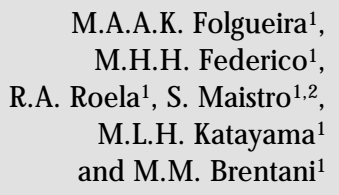

M.A.A.K. Folgueira ${ }^{1}$, M.H.H. Federico ${ }^{1}$, R.A. Roela' ${ }^{1}$ S. Maistro ${ }^{1,2}$, M.L.H. Katayama ${ }^{1}$ and M.M. Brentani ${ }^{1}$

\author{
${ }^{1}$ Disciplina de O ncologia, Departamento de Radiologia, Faculdade de Medicina, \\ Universidade de São Paulo, São Paulo, SP, Brasil \\ ${ }^{2}$ Departamento de Farmacologia, Faculdade de Ciências M édicas, \\ Universidade Estadual de Campinas, Campinas, SP, Brasil
}

\section{Correspondence \\ M.M. Brentani \\ Disciplina de Oncologia \\ Departamento de Radiologia \\ Faculdade de Medicina, USP \\ Av. Dr. Arnaldo, 455 \\ 01246-903 São Paulo, SP \\ Brasil \\ Fax: + 55-11-282-6580}

Research supported by PRONEX (No. 41.960869-00). Publication supported by FAPESP.

Received June 8, 1999

Accepted February 4, 2000

\section{Abstract}

A close correlation between vitamin $\mathrm{D}$ receptor (VDR) abundance and cell proliferation rate has been shown in NIH-3T3 fibroblasts, MCF7 breast cancer and in HL-60 myeloblastic cells. We have now determined if this association occurs in other leukemic cell lines, U937 and K562, and if VDR content is related to c-myc expression, which is also linked to cell growth state. Upon phorbol myristate acetate (PMA) treatment, cells from the three lineages (HL-60, U937 and K562) differentiated and expressed specific surface antigens. All cell lines analyzed were growth inhibited by PMA and the doubling time was increased, mainly due to an increased fraction of cells in the G0/G1 phase, as determined by flow cytometry measurements of incorporated bromodeoxyuridine and cell DNA content. C-myc mRNA expression was down-regulated and closely correlated to cell growth arrest. However, VDR expression in leukemic cell lines, as determined by immunofluorescence and Northern blot assays, was not consistently changed upon inhibition of cell proliferation since VDR levels were down-regulated only in HL-60 cells. Our data suggest that VDR expression cannot be explained simply as a reflection of the leukemic cell growth state.

\section{Introduction}

Vitamin D receptor (VDR) is a nuclear transcription factor, a member of the steroid/ thyroid hormone receptor family, which mediates the physiological actions of its hormone ligand, 1,25-dihydroxyvitamin $\mathrm{D}_{3}(1)$. VDR is expressed in a large variety of mammalian cells from almost every tissue that has been examined thus far. VDR is also present in numerous fresh cancer cells and in a variety of cancer cell lines, as well as in various kinds of hematopoietic cells and leukemic cell lines $(2,3)$.

Regulation of VDR content is still a matter of investigation. VDR abundance seems to be modulated by a variety of hormones, growth factors and developmental signals (4). High levels of VDR expression and high cell proliferation rates were reported in primary cultures of mouse bone (5) and in cultured bovine aortic endothelial cells (6), as well as in NIH$3 \mathrm{~T} 3$ mouse fibroblasts and in MCF-7 human breast cancer cells (4). In addition, our previ- 
ous work showed that in HL-60 myeloblastic cells, VDR expression is correlated with the proliferation rate expressed by the fraction of cells in the G0/G1 phase (7).

Another gene whose expression is tightly linked to the cell growth state is c-myc. This proto-oncogene belongs to a family of related genes involved in the control of normal cell proliferation, induction of neoplasia and apoptosis. C-myc protein is a transcription factor that acts in conjunction with its partner Max, sustaining a program of cell growth through the activation of a specific set of target genes (8). Growth inhibition and cmyc down-regulation were reported upon phorbol 12-myristate 13-acetate (PMA) treatment of leukemic cell lines such as HL-60, U937 (9) and K562 (10). Furthermore, correlations between c-myc and VDR expression in a rat osteogenic sarcoma cell line and mouse skin fibroblasts have been previously demonstrated (11).

In the present work, the association between VDR expression and cell proliferation rate was investigated in three leukemic lineages representing distinct stages of hematopoietic cell differentiation: HL-60, U937 and K562. K562 is an undifferentiated multipotential cell line obtained from a patient with chronic myelogenous leukemia during a blast crisis (12); the HL-60 cell line was established from a patient with incompletely differentiated myeloblastic leukemia (13); U937 is a promonocytic cell line derived from a patient with diffuse histiocytic lymphoma (14). We have attempted to determine in these cell lines if VDR and c-myc expression would follow the same pattern of down-regulation upon PMAinduced growth arrest.

\section{Material and Methods}

\section{Cell culture}

HL-60, U937 and K562 cells (American Type Culture Collection, Rockville, MD, USA) were grown as previously described
(3). Cells at an initial density of $1 \times 10^{5}$ cells/ $\mathrm{ml}$ were treated with vehicle alone (control) or exposed to $60 \mathrm{nM}$ PMA for $96 \mathrm{~h}$ as previously determined in dose (data not shown) or time (7) versus response curves.

\section{Phenotypic analysis by flow cytometry}

The maturation level of HL-60, U937 and K562 cells was evaluated with a broad panel of monoclonal antibodies (MoAb): CD34 (IOM 34, Immunotech, Marseille-Cédex, France), CD33 (WM-54, Dako Corp., Carpinteria, CA, USA), CD13 (WM-47, Dako), CD18 (IOT 18, Immunotech), CD11a (IOT 16, Immunotech), CD11b(2LPM 19c, Dako), CD11c (IOM 11c, Immunotech), CD14 (My-4, Coulter Corp., Hialeah, FL, USA), CD71 (IOA 71, Immunotech), CD41a(IOP 41a, Immunotech) and glycophorin A (Immunotech). Monocytes from peripheral blood of healthy donors were stained with specific antibodies using the Coulter ImmunoPrep EPICS ${ }^{\mathrm{TM}}$ Leukocyte Preparation System in a CoulterQ-PREP Work Station, as recommended by the manufacturer. Cells were labeled in direct or indirect (CD11c) immunofluorescence assays as described (15), and analyzed with an EPICS, Profile II (Coulter) instrument or with a FACscan (Becton-Dickinson Immunocytometry Systems, San Jose, CA, USA). Results are presented as the percentage of cells reacting with the specific MoAb, and positive cells are defined as cells showing greater expression of the antigen than that measured in $99 \%$ of cells labeled only with the isotype control or the 2 nd antibody. Cells were also analyzed for fluorescence intensity. This value was obtained by subtracting the mean fluorescence channel value of cells exposed only to the isotype control or the 2 nd antibody from the mean fluorescence channel value of cells stained with the specific MoAb.

\section{Cell kinetic assays}

Cells were evaluated for DNA content 
using the DNA-intercalating agent propidium iodide (PI) as described (16). Percentage of cells in the G0/G1, S and G2/M phases was evaluated using the Multicycle software (Phoenix Flow Systems, San Diego, CA, USA). Kinetic parameters were evaluated by flow cytometry by correlating bromodeoxyuridine (BrdUrd, a halogenated thymidine analogue, Sigma Chemical Co., St. Louis, MO, USA) incorporation indicating DNA synthesizing cells with DNA quantitation by PI. Cells were processed as described by Schutte et al. (17). Briefly, $10^{7}$ cells $\left(10^{6}\right.$ cells $/ \mathrm{ml}$ ) in the presence or absence of inducers were pulse labeled by incubation with $50 \mu \mathrm{M}$ BrdUrd for $30 \mathrm{~min}$ at $37^{\circ} \mathrm{C}$ in a humidified atmosphere with $5 \% \mathrm{CO}_{2}$. After being washed twice in phosphate-buffered saline (PBS), cells were returned to culture conditions and harvested at progressive time intervals in order to allow progression through the cell cycle. Cells were fixed in $70 \%$ ethanol for at least $12 \mathrm{~h}$, rinsed twice with PBS and incubated with $2 \mathrm{ml}$ pepsin, $0.4 \mathrm{mg} / \mathrm{ml}$ in $0.1 \mathrm{~N} \mathrm{HCl}$, for $30 \mathrm{~min}$ at room temperature (RT) in the dark. Following two washes with PBS, cells were treated with $2 \mathrm{ml} 2 \mathrm{~N} \mathrm{HCl}$ for 30 min at $37^{\circ} \mathrm{C}$ and washed twice with borax, $\mathrm{pH} 8.5$, and twice with $1 \%$ PBS/BSA. Cells were then incubated with $20 \mu$ fluorescein (FITC) anti-BrdUrd conjugate (BectonDickinson) in the dark for $30 \mathrm{~min}$ at RT, washed in PBS and resuspended in $500 \mu \mathrm{l}$ PBS containing $5 \mu \mathrm{g} / \mathrm{ml}$ PI and RNase. The labeling index (LI) was estimated as the percentage of cells labeled with the monoclonal antibody directed to BrdUrd. Duration of the $\mathrm{S}$ phase (DNA synthesis time, Ts) and potential doubling time (Tpot) were calculated based on the relative movement of cells that incorporated BrdUrd and progressed through the cell cycle (18).

\section{VD R evaluation using a specific monoclonal antibody}

VDR expression was evaluated in indi- rect immunofluorescence assays using a specific murine MoAb. Cells were fixed in $70 \%$ cold ethanol and maintained at $-20^{\circ} \mathrm{C}$ for at least $12 \mathrm{~h}$, washed twice in PBS and incubated with $13 \mu \mathrm{g} / \mathrm{ml}$ anti-VDR (VD2F12) (19) for $60 \mathrm{~min}$. Positivity for the marker was calculated by enumerating the cells located above the channel where $1 \%$ of positivity was obtained for the background stain. Fluorescence intensity, which reflects the number of antigen molecules/cell, was evaluated on the basis of the mean fluorescence channel as described in phenotypic analysis.

\section{RNA isolation and Northern blot assays}

Total RNA was prepared from $10^{7}$ cells using $5.7 \mathrm{M} \mathrm{CsCl}, \mathrm{pH} 7.0$, gradient centrifugation (20). Twenty-microgram samples were electrophoresed on $1 \%$ agarose- $3 \%$ formaldehyde gels and the RNA was transferred to Hybond N nylon filters (Amersham International, Little Cholfont, Buckinghamshire, England) which were hybridized in 50\% formamide, 5X SSPE, $0.2 \%$ SDS, $5 \%$ dextran sulfate, $5 \mathrm{X}$ Denhardt's solution containing $100 \mu \mathrm{g} / \mathrm{ml}$ salmon sperm DNA, and $3 \mathrm{x}$ $10^{6} \mathrm{cpm} / \mathrm{ml}\left[\alpha^{32} \mathrm{P}\right] \mathrm{dCTP}$ (Amersham International) oligo-labeled specific probe using the random primer labeling technique (Klenow fragment of $E$. coli DNA polymerase, Gibco BRL, Gaithersburg, MD, USA) for $20 \mathrm{~h}$ at $42^{\circ} \mathrm{C}$. The following fragments were used as probes: a $1.7-\mathrm{kb}$ EcoRI fragment of human c-myc cDNA (21), and a $2.1-\mathrm{kb}$ fragment of human VDR cloned at the EcoRI site of pGEM (22). Membranes were washed for $15 \mathrm{~min}$, twice at RT in $2 \mathrm{X}$ SSPE, $0.1 \%$ SDS, once in $1 \mathrm{X}$ SSPE, $0.1 \%$ SDS, once in 0.2X SSPE, $0.1 \%$ SDS, and finally for $30 \mathrm{~min}$ at $52^{\circ} \mathrm{C}$ in $0.1 \mathrm{X} \mathrm{SSPE}$ and $0.1 \%$ SDS. Hybridization with the $18 \mathrm{~S}$ ribosomal RNA probe (1.9-kb fragment cloned at the SalI/EcoRI site of plasmid pBR322) (23) was subsequently performed to check for equivalence of RNA loading. The 4.6, 2.2 and 1.9 hybridizing bands encountered 
were consistent with RNA coding for VDR, c-myc and 18S rRNA, respectively. Band intensities in autoradiograms were quantified by densitometric scanning (UltroScan XL, Pharmacia LKB Biotechnology, Uppsala, Sweden) and data are reported as the ratio of specific mRNA to $18 \mathrm{~S}$ rRNA. All solutions were prepared as previously described (24).

\begin{tabular}{|c|c|c|c|c|c|}
\hline \multicolumn{6}{|c|}{$\begin{array}{l}\text { MoAb-stained cells were analyzed as percent of cells expressing the antigen. Immu- } \\
\text { nophenotyping of monocytes obtained from peripheral blood samples from normal } \\
\text { donors is also presented. Results are reported as means } \pm \text { SD. } * P<0.05 \text { compared to } \\
\text { control uninduced cells (Mann-Whitney test). }\end{array}$} \\
\hline & \multicolumn{2}{|c|}{ HL-60 cells } & \multicolumn{2}{|c|}{ U937 cells } & \multirow{2}{*}{$\begin{array}{l}\text { Mono } \\
N=3\end{array}$} \\
\hline & $\begin{array}{c}C \\
N=11\end{array}$ & $\begin{array}{l}\text { PMA } \\
N=4\end{array}$ & $\begin{array}{c}C \\
N=6\end{array}$ & $\begin{array}{l}\text { PMA } \\
N=3\end{array}$ & \\
\hline CD33 & $52.7 \pm 21.7$ & $23.7 \pm 18.3$ & $47.1 \pm 17.9$ & $40.9 \pm 5.8$ & $37.1 \pm 31.6$ \\
\hline $\mathrm{CD} 13$ & $99.6 \pm 0.60$ & $98.9 \pm 1.60$ & $99.8 \pm 0.10$ & $99.9 \pm 0.2$ & $61.6 \pm 17.1$ \\
\hline CD18 & $86.7 \pm 11.3$ & $98.7 \pm 0.70$ & $99.7 \pm 0.30$ & $99.9 \pm 0.0$ & $98.2 \pm 0.60$ \\
\hline CD1la & $77.7 \pm 15.9$ & $97.8 \pm 2.30 *$ & $99.2 \pm 0.80$ & $99.8 \pm 0.1$ & $97.9 \pm 1.20$ \\
\hline CD11b & $4.90 \pm 4.20$ & $41.3 \pm 12.1^{*}$ & $37.0 \pm 10.4$ & $94.5 \pm 4.7 *$ & $93.8 \pm 0.90$ \\
\hline CD11c & $12.0 \pm 8.10$ & $61.6 \pm 11.3^{*}$ & $13.5 \pm 8.30$ & $31.8 \pm 8.4^{*}$ & $78.3 \pm 10.3$ \\
\hline CD14 & $0.41 \pm 0.30$ & $3.80 \pm 1.20$ & $24.7 \pm 15.9$ & $20.4 \pm 7.5$ & $82.2 \pm 5.90$ \\
\hline CD71 & $67.0 \pm 21.8$ & $21.4 \pm 10.9 *$ & $69.5 \pm 23.7$ & $33.2 \pm 1.9 *$ & $48.8 \pm 18.5$ \\
\hline
\end{tabular}

Table 1 - Phenotypic analysis of HL-60 and U937 cells in the absence (C, control) or presence of phorbol 12-myristate 13-acetate (PMA) for $96 \mathrm{~h}$ and normal monocytes (Mono).

\begin{tabular}{|c|c|c|}
\hline \multirow{2}{*}{\multicolumn{3}{|c|}{$\begin{array}{l}\text { Table } 2 \text { - Surface antigen expression in } \mathrm{K} 562 \text { cells } \\
\text { uninduced (C, control) or exposed for } 96 \mathrm{~h} \text { to } \\
\text { phorbol } 12 \text {-myristate } 13 \text {-acetate (PMA). } \\
\text { Results are reported as mean } \pm \text { SD percentage of } \\
\text { positive cells. } * \mathrm{P}<0.05 \text { compared to K562 control } \\
\text { cells (Mann-Whitney test). Glyc-A, Glycophorin A. }\end{array}$}} \\
\hline & & \\
\hline & $\begin{array}{c}C \\
N=6\end{array}$ & $\begin{array}{l}\text { PMA } \\
N=6\end{array}$ \\
\hline CD34 & $5.4 \pm 3.9$ & $1.3 \pm 0.8$ \\
\hline CD33 & $0.8 \pm 0.5$ & $5.5 \pm 5.0$ \\
\hline $\mathrm{CD} 13$ & $1.2 \pm 0.8$ & $11.4 \pm 10.1$ \\
\hline $\mathrm{CD} 18$ & $1.1 \pm 0.1$ & $7.5 \pm 2.6^{*}$ \\
\hline CD11a & $2.0 \pm 0.6$ & $10.1 \pm 3.7 *$ \\
\hline CD11b & $1.8 \pm 1.1$ & $0.5 \pm 0.3$ \\
\hline CD11c & $4.2 \pm 5.7$ & $1.8 \pm 1.1$ \\
\hline CD41a & $0.8 \pm 0.5$ & $11.1 \pm 4.7^{*}$ \\
\hline Glyc-A & $25.3 \pm 11.8$ & $2.2 \pm 1.2^{*}$ \\
\hline CD71 & $71.4 \pm 13.4$ & $6.0 \pm 1.5^{*}$ \\
\hline
\end{tabular}

\section{Statistical analysis}

Statistical analysis was carried out using the Mann-Whitney two-tailed test, with the level of significance set at $\mathrm{P}<0.05$.

\section{Results}

A broad panel of monoclonal antibodies was used to recognize surface antigens regulated during induction of cell maturation. It comprised CD11a, CD11b, CD11c and $\mathrm{CD} 18$, members of the $\mathrm{B2}$ family of leukocyte integrins; CD71, or transferrin receptor, expressed by most proliferating cells; CD14, the lipopolysaccharide receptor; CD34, a glycoprotein present on hematopoietic precursor cells; CD33, a marker for colonyforming units for granulocytes, erythrocytes, monocytes, and megakaryocytes; CD13, an antigen present during the early phase of myeloid commitment; CD41a which reacts with glycoprotein IIb complexed with gpIIIa to form the main fibrinogen receptor, expressed by megakaryocytes and platelets, and glycophorin A, a transmembrane sialoglycoprotein expressed by erythroid cells (25).

The proportion of HL-60 cells expressing each surface marker is summarized in Table 1. A high percentage ( $>50 \%)$ of HL60 myeloblastic cells expressed CD33, CD13, CD18, CD11a and CD71 molecules. After a 96-h exposure to $60 \mathrm{nM}$ PMA, HL-60 cells differentiated along the monocytic/macrophagic pathway and the fraction of cells expressing CD11b, CD11c and CD1 1a antigens increased, the later becoming similar to that observed in normal monocytes. There was a reduction in the proportion of cells expressing CD71 molecules, whereas we could not detect changes in CD13, CD14, CD33 or CD18 expression.

A high proportion (>90\%) of U937 myelomonoblastic uninduced cells exhibited CD13, CD11a and CD18 antigens and $24 \%$ expressed CD14 antigen (Table 1). Upon $96 \mathrm{~h}$ of PMA treatment, the percentage of 
cells presenting CD11b and CD11c molecules was enhanced and reached 94 and $31 \%$, respectively, whereas expression of CD14 was unaffected. Since a high fraction of U937 cells already expressed the CD11a antigen, we observed that the number of molecules per cell, evaluated by fluorescence intensity, was increased and reached twice the value of uninduced cells. After this period, PMA also induced a decrease in the proportion of cells expressing the CD71 antigen from 69 to $33 \%$.

As shown in Table 2, 25\% of K562 cells expressed glycophorin A and $71 \%$ presented CD71. Both surface antigens were diminished upon exposure to PMA for $96 \mathrm{~h}$. There was a weak induction of CD41a, CD11a and CD18 molecules, which were absent in control cells.

Proliferation was evaluated by the fraction of cells with typical G0/G1 phase DNA content following PI staining. To better understand the effects of inducers on these cell lines, a more specific analysis of cell cycle kinetics was performed using BrdUrd. By competing with thymidine, BrdUrd is incorporated into newly synthesized DNA and can be detected by flow cytometry after fluorescein-labeled anti-BrdUrd antibody application. The cohort of BrdUrd-labeled cells (LI) may be followed at various time points in the cell cycle, providing kinetic estimates of DNA Ts and cellular Tpot, as demonstrated in Figure 1.

HL-60 cells were growth inhibited after PMA treatment as verified by an accumulation of cells in the $\mathrm{G} 0 / \mathrm{G} 1$ phase of the cell cycle (Table 3) that increased from 52\% (control cells) to $87 \%$ (PMA-treated cells). PMA induction was associated with an increase in Tpot, which doubled compared to unexposed cells and reached $50 \mathrm{~h}$, basically due to a decrease in LI from $49 \%$ (control cells) to $26 \%$.

U937 cells were growth arrested upon PMA treatment, so that it was not possible to calculate the Tpot, as cells were no longer synthesizing DNA. K562 cells showed the shortest Tpot $(12 \mathrm{~h})$ among the three cell lines analyzed, mainly due to their shorter DNA synthesis time. Upon PMA induction, Tpot was enhanced to $18 \mathrm{~h}$. However, only
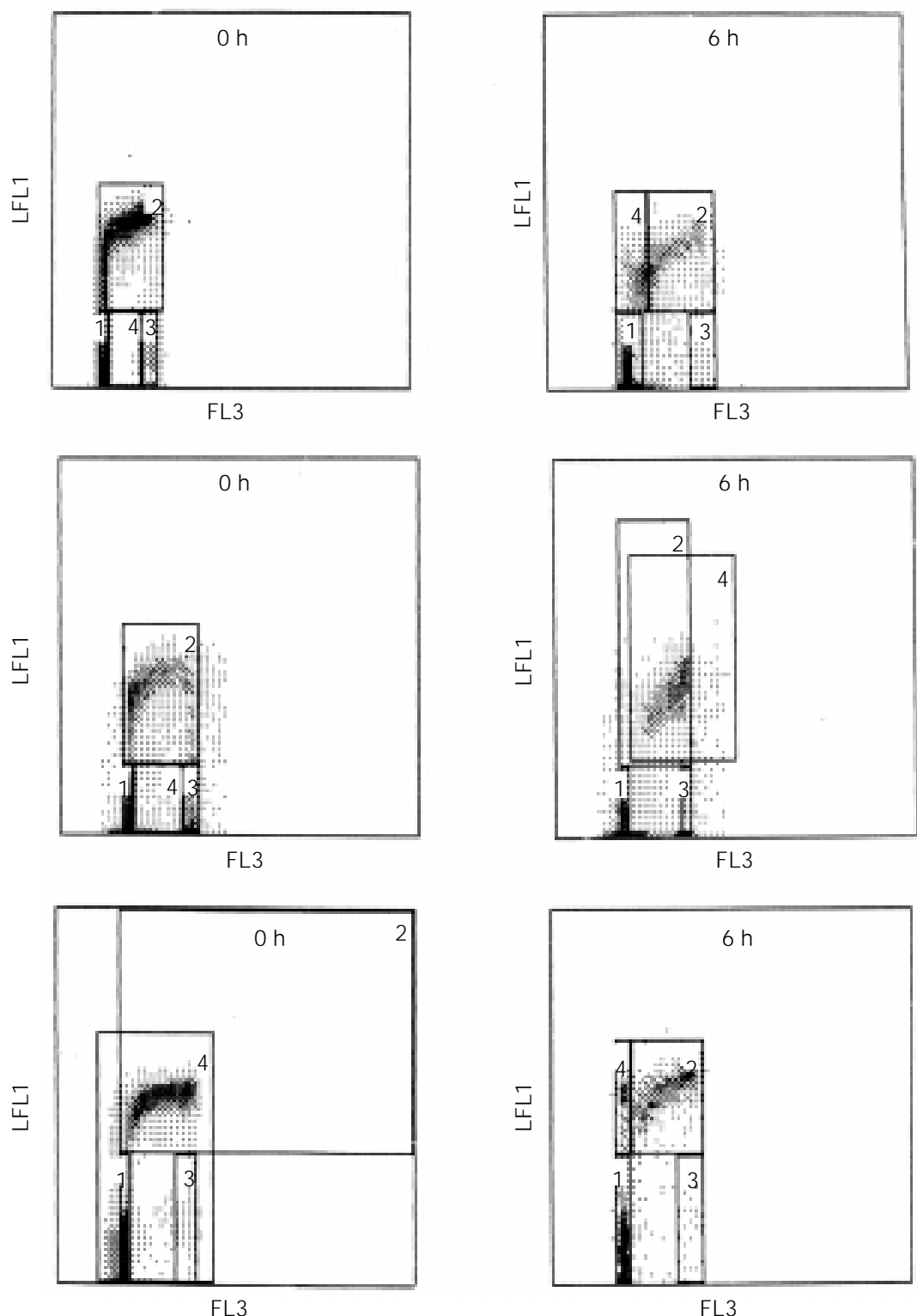

Figure 1 - Kinetic parameters of leukemic cell lines. HL-60 (1st line), U937 (2nd line) and K562 (3rd line) uninduced cells were exposed to BrdUrd for 30 min and harvested immediately after incubation (time $0 \mathrm{~h}$, on the left) or after a 6 -h exposure (on the right). In the histograms, BrdUrd incorporation analyzed as LFL1 is represented on the y-axis, and DNA content evaluated with the intercalating agent PI appears on the $\mathrm{x}$-axis as FL3. Bitmaps 1 and 3 show BrdUrd-negative cells in the G0/G1 or G2/M phase, respectively. Cells that have incorporated BrdUrd appear on bitmap 2 in the histograms on the left and on bitmaps 2 and 4 in the histograms on the right. The histograms shown are representative of one of three experiments performed. 
Table 3 - Kinetic parameters of 96-h uninduced (C, control) or PMA-exposed (P) HL-60, U937 or K562 cells.

Cells were analyzed for the fraction of cells in the G0/G1 phase as described in Methods. The fraction of cells in the G0/G1 phase at the beginning of time culture did not differ from the fraction of cells maintained for $96 \mathrm{~h}$ in the absence of inducer. Kinetic parameters were evaluated by flow cytometry using the bivariate method of BrdUrd incorporation and cellular DNA content. Labeling index (LI) was estimated by the percentage of cells synthesizing DNA which incorporated BrdUrd and were labeled with a monoclonal antibody. Duration of S phase (DNA synthesis time, Ts) and potential doubling time (Tpot) were calculated based on the relative movement of cells that incorporated BrdUrd and progressed through the cell cycle. Results are reported as means $\pm \mathrm{SD}$ of three representative assays. ${ }^{*} \mathrm{P}<0.05$ compared to control ( $\mathrm{M}$ annWhitney test). ND, Not determined.

\begin{tabular}{lllcc}
\hline & G0/G1 (\%) & \multicolumn{1}{c}{ LI (\%) } & Ts (h) & Tpot (h) \\
\hline HL-60 C & $52.5 \pm 6.4$ & $49.4 \pm 6.3$ & $12.1 \pm 0.6$ & $24.7 \pm 2.5$ \\
HL-60 P & $87.6 \pm 2.5^{*}$ & $26.2 \pm 0.4^{*}$ & $13.1 \pm 1.5$ & $50.6 \pm 6.4^{*}$ \\
U937 C & $52.4 \pm 7.3$ & $43.2 \pm 6.2$ & $16.3 \pm 4.0$ & $37.5 \pm 5.3$ \\
U937 P & $88.7 \pm 6.9 *$ & $4.90 \pm 2.9 *$ & ND & ND \\
K562 C & $32.6 \pm 1.6$ & $55.8 \pm 8.1$ & $6.8 \pm 0.5$ & $12.2 \pm 1.4$ \\
K562 P & $48.5 \pm 4.7^{*}$ & $44.5 \pm 4.4$ & $8.5 \pm 1.6$ & $18.9 \pm 1.8^{*}$
\end{tabular}
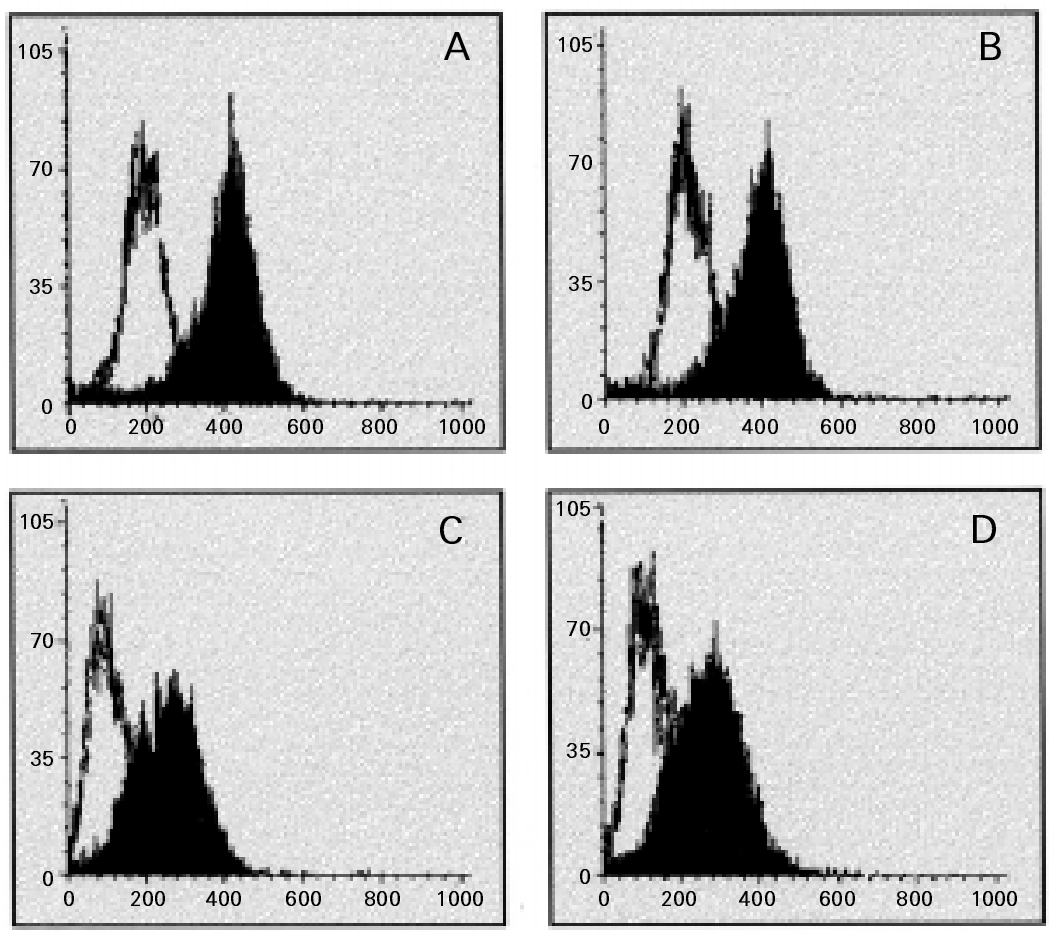

Figure 3 - Vitamin D receptor (VDR) protein expression in U937 (A,B) or K562 (C,D) cells uninduced $(A, C)$ or treated for $96 \mathrm{~h}$ with PMA $(B, D)$. VDR content was evaluated with a monoclonal antibody in flow cytometry analysis. In the histograms, the cell number is shown on the $y$-axis and the fluorescence channel number on the x-axis. The open area represents the nonspecific staining and the filled area represents cells specifically labeled with anti-VDR antibody. These experiments were performed on 6 different occasions with similar results.
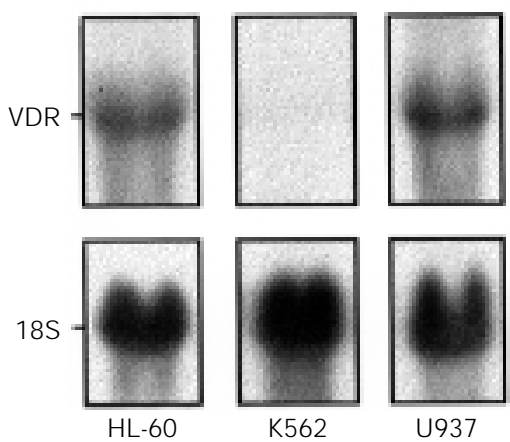

Figure 2 - Vitamin D receptor (VDR) mRNA expression in HL-60, K562 and U937 cells. Twenty micrograms of total RNA obtained from uninduced cells was used for Northern blot analysis of VDR as described in Material and Methods. Blots were simultaneously probed for the expression of 18S rRNA as a control for RNA loading. The 4.6 and 1.9 hybridizing bands are consistent with RNA coding for VDR and 18S rRNA, respectively.

small variations were observed in LI and Ts (Table 3).

To determine whether there were changes in VDR expression during induction of differentiation of U937 and K562 cell lines, immunofluorescence and Northern blot assays were performed. U937 cells expressed a higher amount of VDR mRNA than HL-60 cells, whereas VDR message could scarcely be detected in K562 cells (Figure 2). VDR protein expression was detected in $78.2 \%( \pm$ $18.1 ; \mathrm{N}=6$ ) of U937 control cells and this proportion was maintained in PMA-treated cells $(76.3 \pm 8.4 \% ; \mathrm{N}=6)$, as determined in immunofluorescence assays (Figure 3). Accordingly, VDR mRNA steady state levels did not show major changes in PMA-exposed U937 cells as compared to untreated cells (Figure 4). Although the percentage of PMA-treated K562 cells labeled with antiVDR monoclonal antibody $(60.1 \pm 16.3 \%$; $\mathrm{N}=6$ ) remained unchanged as compared to control cells $(55.3 \pm 21.1 \% ; \mathrm{N}=6)$ (Figure 3), VDR mRNA was enhanced two-fold upon PMA induction (Figure 4).

Expression of c-myc mRNA was compared to VDR mRNA expression upon in- 

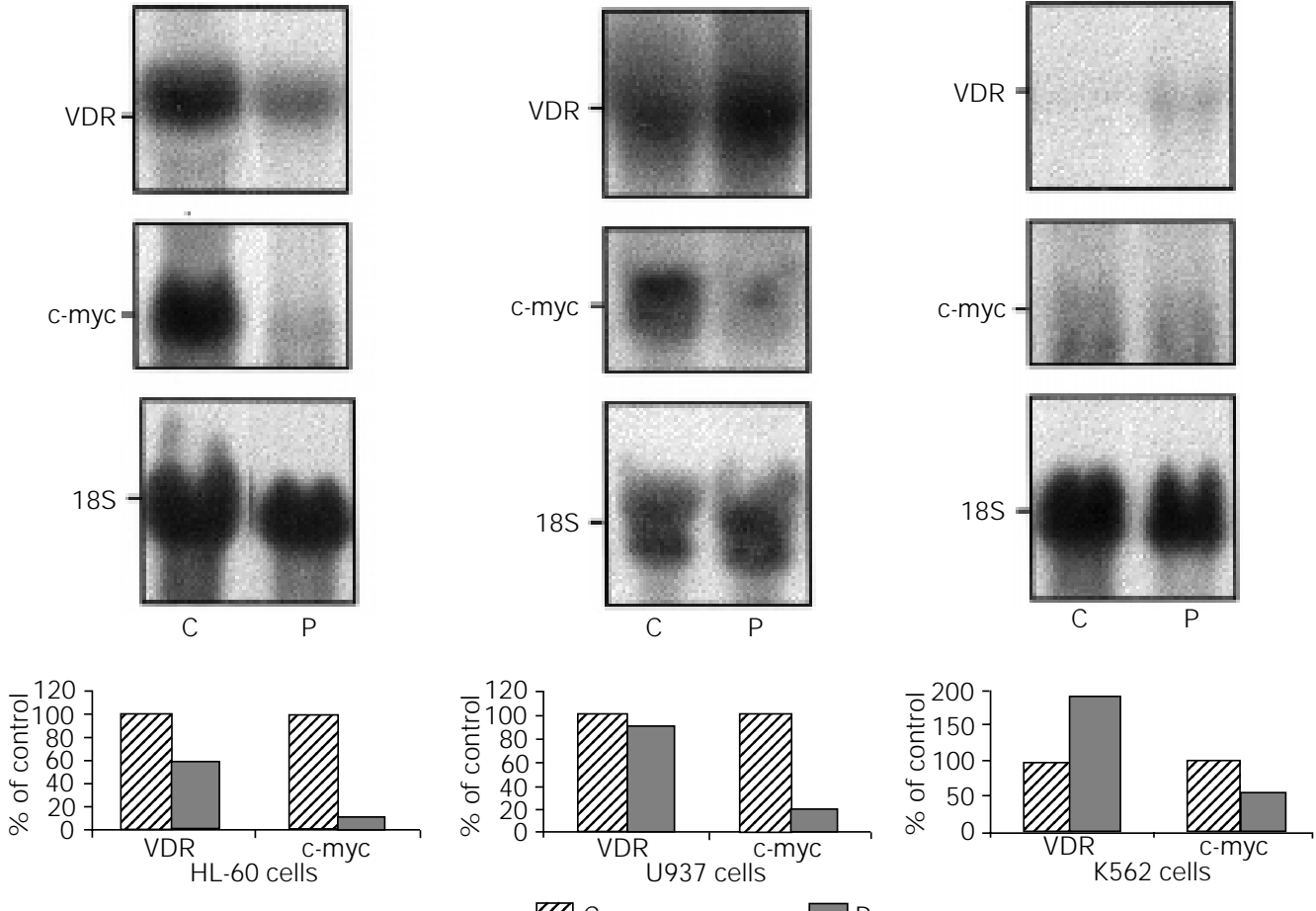

ZZC

duction of differentiation of the three cell lines (Figure 4). Cells of all three lineages presented c-myc in Northern blot assays that followed a similar pattern of modulation upon PMA induction, as the transcripts were down-regulated when compared to uninduced cells. Specifically in HL-60 cells, cmyc mRNA levels almost disappeared after a 96-h PMA exposure, and in K562, PMA treatment did not cause such an intense reduction as that observed on the other two cell lines.

\section{Discussion}

After phorbol ester treatment, HL-60 and U937 cells did not achieve a phenotype similar to that observed on monocytes obtained from peripheral blood of normal donors. We observed an enhancement in CD11a, CD11b and $\mathrm{CD} 11 \mathrm{c}$ antigen expression consistent with the increased steady state levels of each respective message, as also shown by other authors (26-28). However, the CD14 molecule, which is the endotoxin receptor highly expressed in human monocytes (29), was not induced upon PMA exposure of both cells. These data agree with those reported by some authors $(30,31)$ but not with those reported by others (32). Various factors might be involved in these different responses such as source of serum and inducer concentration, in addition to differences occurring in cells during repeated passages. As a matter of fact, we observed that a slight proportion of U937-uninduced cells already expressed the CD14 antigen as reported by Hewison et al. (31), but not by Gidlund et al. (33).

Phorbol ester induction of K562 cells led to the appearance of both megakaryocytic and myelomonocytic markers, as already reported (34). According to Silver et al. (35), PMA stimulates K562 cells to synthesize the B integrin subunit gpIIIa. Our cells, however, did not reach the previously reported values. The antibody we used, which recognizes the glycoprotein IIb/IIIa complex and is not specific for glycoprotein gpIIIa, could explain this fact. The strong reduction of cell surface transferrin receptors observed in PMA-treated K562 cells as compared to a small reduction in kinetic parameters could
Figure 4 - Vitamin D receptor (VDR) and c-myc mRNA expression in uninduced $(C$, control) or 96-h PMA-treated (P) HL-60, U937 and K562 cells. Total RNA was subjected to Northem blot analysis and filters were sequentially hybridized with ${ }^{32} \mathrm{P}$-labeled probes for VDR, c-myc and for reference $18 \mathrm{~S}$ rRNA. The autoradiograms shown above were quantified by densitometric scanning and data are reported as ratio of the amount of specific mRNA to $18 \mathrm{~S}$ rRNA, as illustrated in graphs below the autoradiograms. A value of $100 \%$ was assigned to unexposed cells. Similar results were obtained in two separate experiments. 
be attributed to an immediate PMA action leading to receptor endocytosis, followed by decreased synthesis upon prolonged exposure. These effects might be regulated by protein kinase $\mathrm{C}$ (PKC), having no association with the acquisition of the differentiated phenotype or growth arrest (36).

The kinetic properties of HL-60-uninduced cells determined by us are similar to those described by Mehdi et al. (37). The potential doubling time of U937 cells resulting from the double label technique confirms previous data obtained by analysis of growth curves (38). However, in K562 cells, the potential doubling time we obtained by bivariate distributions of BrdUrd labeling versus DNA content was lower than that determined before by growth curve experiments (39). Discrepancies in cell behavior could be a consequence of differences occurring during progressive cell passages. In PMA-treated K562 cells, we did not observe the polyploidization reported by Yen et al. (39). This fact could be explained by the lower rate of differentiation attained by our cells upon PMA exposure. The present data indicate that growth inhibition induced by PMA in the three cell lines analyzed is mainly a consequence of the accumulation of cells in the G0/G1 phase as DNA synthesis time was not prolonged. To our knowledge, this is the first report of the kinetic parameters of the three leukemia cell lines upon PMA induction.

VDR and c-myc mRNA expression is regulated differently in the three cell lines studied and only the decrease in c-myc transcripts paralleled cell growth inhibition, in accordance with previous studies describing c-myc down-regulation upon PMA stimulation of K562 (10), HL-60 and U937 cells (9).

We have already shown that in HL-60 cells VDR expression is transcriptionally regulated and decreases as cell growth is inhibited by PMA (7). In the present study, we found that in this cell line both VDR and c-myc mRNA expression seem to be directly related to cell proliferation, in agreement with the findings of Manolagas et al. (11), who reported that VDR and c-myc expression varies in a parallel fashion in mouse skin fibroblasts.

In U937 cells, the effects of PMA appear to be more complex, since PMA causes a decrease in c-myc mRNA steady state level without a parallel reduction in VDR expression. The reason for this observation is not clear since PMA-exposed U937 cells were growth arrested and differentiated along the monocytic/macrophagic pathway in a similar pattern as HL-60 cells. Hewison et al. (31) showed that PMA treatment of U937 cells can increase 1,25-dihydroxyvitamin $\mathrm{D}_{3}$ levels as a result of enhanced $1 \alpha$ hydroxylase activity. Vitamin D could, in turn, increase its own receptor stability, as previously reported (40). Hence, such discrepancies might be attributed in part to homologous VDR up-regulation.

K562 cells contained the lowest amount of VDR mRNA among the three cell lines analyzed, as previously demonstrated (2). In this cell line, VDR and c-myc mRNA expression was modulated in an opposite fashion, similar to the data reported by Hulla et al. (41) for colon adenocarcinoma cells. VDR mRNA and protein results were poorly correlated, suggesting that at least partial regulation of VDR levels occurs post-transcriptionally. We speculate that the up-regulated mRNA was not translated into protein, or the protein was rapidly degraded, or yet again a defective protein was translated, probably at the DNA binding site, preventing recognition by the site-specific monoclonal antibody we used (19). On the other hand, even though the proliferation rate was diminished upon PMA treatment of K562 cells, only $48.5 \%$ of cells were in the G0/G1 phase, which contains the least amount of VDR as observed in HL-60 cells (7).

Moreover, the VDR gene promoter was characterized and found to include potential binding sites for specific transcriptional regu- 
lators such as AP-1 and NFkB, which could mediate phorbol ester inducibility (42). Phorbol esters are a group of compounds whose actions are mediated in part by PKC. At present, 11 isotypes of PKC are known to feature different cell type pattern of expression, suggesting characteristic functions for each PKC isoform (43). We have found that $\mathrm{PKC} \gamma$ isoform mRNA is only expressed by $\mathrm{K} 562$ cells and is absent in the other two cell lines (data not shown). This variability could also account for the different responses of VDR expression elicited by PMA in these leukemic cell lines.

Either differences in the origin of these cell lines or differential VDR content constitutively expressed by each cell lineage could be involved in subtle signal pathways that take place during PMA induction. We also speculate that the differential oncogene expression occurring in these cell lines induces distinct pathways, which blunt the effect of growth arrest on VDR levels. We have recently described that VDR expression and modulation can be altered by oncogenic transfection (44).

\section{References}

1. DeLuca HF \& Zierold C (1998). Mechanisms and functions of vitamin D. Nutrition Reviews, 56: S4-S10.

2. Kizaki M, Norman AW, Bishop J E, Lin CW, Karmakar A \& Koeffler HP (1991). 1,25Dihydroxyvitamin $D_{3}$ receptor RNA: Expression in hematopoietic cells. Blood, 77: 1238-1247.

3. Feldman J, Federico MHH, Sonohara S, Katayama MLH, Koike MAA, da Silva M RP \& Brentani MM (1993). Vitamin $D_{3}$ binding activity during leukemic cell differentiation. Leukemia Research, 17: 97-101.

4. Krishnan AV \& Feldman D (1997). Regulation of vitamin $D$ receptor abundance. In: Feldman D, Glorieux FH \& Pike J W (Editors), Vitamin D. Academic Press, San Diego, 179-200.

5. Chen TL \& Feldman D (1981). Regulation of 1,25-dihydroxyvitamin $D_{3}$ receptors in cultured mouse bone cells. Correlation of receptor concentration with the rate of
In conclusion, our data suggest that VDR expression cannot be explained simply as a reflection of the growth state of leukemic cells.

\section{Acknowledgments}

We thank Prof. Hector F. DeLuca, Department of Biochemistry, University of Wisconsin, Madison, WN, USA, for the generous gift of an anti-VDR monoclonal antibody (VD2F12); Prof. J. Shine, California Biotechnology Inc., Mountain View, CA, USA, and Dr. T.H. Rabbitts, Laboratory of Molecular Biology, Cambridge, England, and Dr. Norman Arnheim, Biochemistry Department, State University of New York, Stony Brook, NY, USA, for the kind donation of probes for VDR, c-myc and $18 \mathrm{~S}$ rRNA. We are very grateful to Dr. Bert Schutte and Mrs. Marie Hélène Lenders, University of Limburg, Maastricht, The Netherlands, for helpful assistance in establishing the cell kinetic techniques, and to Mrs. Maria do Rosário Pereira da Silva for assistance with cell culture. cell division. J ournal of Biological Chemistry, 256: 5561-5566.

6. Merke J, Milde P, Lewicka S, Hugel $U$, Klaus G, Mangelsdorf DJ , Haussler MR, Rauterberg EW \& Ritz E (1989). Identification and regulation of 1,25-dihydroxyvitamin $D_{3}$ receptor activity and biosynthesis of 1,25-dihydroxyvitamin $D_{3}$. Studies in cultured aortic endothelial cells and human dermal capillaries. J ournal of Clinical Investigation, 83: 1903-1915.

7. Folgueira MAAK, Federico $\mathrm{MHH}$, Katayama MLH, Silva MRP \& Brentani MM (1998). Expression of vitamin D receptor (VDR) in HL-60 cells is differentially regulated during the process of differentiation induced by phorbol ester, retinoic acid or interferon- $\gamma$. J ournal of Steroid Biochemistry and Molecular Biology, 66: 193-201.

8. Bouchard C, Staller P \& Eilers M (1998). Control of cell proliferation by Myc.
Trends in Cell Biology, 8: 202-206.

9. Larsson L-G, Pettersson M, Öberg F, Nilsson K \& Lüscher B (1994). Expression of mad, mxil, max and c-myc during induced differentiation of hematopoietic cells: opposite regulation of mad and cmyc. Oncogene, 9: 1247-1252.

10. Delgado $M D$, Lerga $A$, Cañelles $M$, Gómez-Casares MT \& León J (1995). Differential regulation of Max and role of CMyc during erythroid and myelomonocytic differentiation of K562 cells. Oncogene, 10: 1659-1665.

11. Manolagas SC, Provvedini DM, Murray EJ , Murray SS, Tsonis PA \& Spandidos DA (1987). Association between the expression of the c-myc oncogene mRNA and the expression of the receptor protein for 1,25-dihydroxyvitamin $D_{3}$. Proceedings of the National Academy of Sciences, USA, 84: 856-860.

12. Alitalo R (1990). Induced differentiation of 
K562 leukemia cells: a model for studies of gene expression in early megakaryoblasts. Review. Leukemia Research, 14: 501-514.

13. Dalton WT, Ahearn MJ, McCredie KB, Freireich EJ , Stass SA \& Trujillo J M (1988). $\mathrm{HL}-60$ cell line was derived from a patient with FAB-M2 and not FAB-M3. Blood, 71: 242-247.

14. Sundström C \& Nilsson K (1976). Establishment and characterization of a human histiocytic lymphoma cell line (U-937). International J ournal of Cancer, 17: 565577.

15. Coligan J E, Kruisbeek AM, Margulies DH, Shevach EM \& Strober W (1997). Current Protocols in Immunology. J ohn Wiley \& Sons, Inc., New York.

16. Vindelov LL \& Christensen IJ (1990). A review of techniques and results obtained in one laboratory by an integrated system of methods designed for routine clinical flow cytometric DNA analysis. Cytometry, 11: 753-770.

17. Schutte B, Reynders MMJ, Van Assche CLMVJ , Hupperets PSGJ , Bosman FT \& Blijham GH (1987). An improved method for the immunocytochemical detection of bromodeoxyuridine labeled nuclei using flow cytometry. Cytometry, 8: 372-376.

18. Begg AC, MCNally NJ, Shrieve DC \& Karcher H (1985). A method to measure the duration of DNA synthesis and the potential doubling time from a single sample. Cytometry, 6: 620-626.

19. Dame MC, Pierce EA, Prahl J M, Hayes CE \& DeLuca HF (1986). Monoclonal antibodies to the porcine intestinal receptor for 1,25-dihydroxyvitamin $D_{3}$ : interaction with distinct receptor domains. Biochemistry, 25: 4523-4534.

20. Glisin V, Crvenjakov R \& Byus C (1974). Ribonucleic acid isolated by cesium chloride centrifugation. Biochemistry, 13: 2633-2637.

21. Watt R, Stanton LW, Marcu KB, Gallo RC, Croce CM \& Rovera G (1983). Nucleotide sequence of cloned cDNA of human cmyc oncogene. Nature, 303: 725-728.

22. Faraco J H, Morrison NA, Baker A, Shine J \& Frossard PM (1989). Apal dimorphism at the human vitamin $D$ receptor gene locus. Nucleic Acids Research, 17: 2150.

23. Arnheim N (1979). Characterization of mouse ribosomal gene fragments purified by molecular cloning. Gene, 7: 83-96.

24. Maniatis T, Fritsch EF \& Sambrook J (1989). Molecular Cloning: A Laboratory Manual. 2nd edn. Cold Spring Harbor Laboratory, New York.

25. Drexler HG, Gignac SM \& Minowada J
(1988). Routine immunophenotyping of acute leukaemias. Blut, 57: 327-339.

26. Back $A L$, Gollahon $K A$ \& Hickstein DD (1992). Regulation of expression of the leukocyte integrin CD11a (LFA-1) molecule during differentiation of HL-60 cells along the monocyte/macrophage pathway. J ournal of Immunology, 148: 710714.

27. Pahl HL, Rosmarin AG \& Tenen DG (1992). Characterization of the myeloid specific CD11b promoter. Blood, 79: 865870.

28. Rubio MA, Lopez-Rodriguez C, Nueda A, Aller $P$, Armesilla $A L$, Vega MA \& Corbí AL (1995). Granulocyte-macrophage colony stimulating factor, phorbol ester, and sodium butyrate induce the CD11c integrin gene promoter activity during myeloid cell differentiation. Blood, 86: 37153724.

29. Antal-Szalmas $P$, Van StrijpJ AG, Weersink AJ L, Verhoef J \& Van Kessel KPM (1997). Quantitation of surface CD14 on human monocytes and neutrophils. J ournal of Leukocyte Biology, 61: 721-728.

30. Trayner ID, Bustorff T, Etches AE, Mufti GJ , Foss Y \& Farzaneh F (1998). Changes in antigen expression on differentiating HL60 cells treated with dimethylsulphoxide, all-trans retinoic acid, $1 \alpha, 25$-dihydroxyvitamin $\mathrm{D}_{3}$ or 12-tetradecanoyl phorbol13-acetate. Leukemia Research, 22: $537-$ 547.

31. Hewison $M$, Brennan A, Singh-Ranger $R$, Walters J C, Kratz DR \& O'Riordan J LH (1992). The comparative role of 1,25-dihydroxycholecalciferol and phorbol esters in the differentiation of the U937 cell line. Immunology, 77: 304-311.

32. Rossi $P$, Chini L, Fattorossi A, Gidlund $M$, Galli E, Laan K, J ondal $M \&$ Wigzell $H$ (1987). 1,25-dihydroxyvitamin $D_{3}$ and phorbol esters (TPA) may induce select in vitro differentiation pathways in the HL60 promyelocytic cell line. Clinical Immunology and Immunopathology, 44: 308-316.

33. Gidlund M, Rossi $P$, Cotran $P$, Ramstedt $\mathrm{U} \&$ Wigzell H (1988). In human monocytes a strong correlation exists between expression of the M3 antigen, Fc-mediated phagocytic activity and failure to participate in extracellular antibody-dependent cytotoxicity. European J oumal of Immunology, 18: 477-480.

34. Gómez-Casares MT, Delgado MD, Lerga A, Crespo P, Quincoces AF, Richard C \& León J (1993). Down regulation of c-myc gene is not obligatory for growth inhibition and differentiation of human myeloid leukemia cells. Leukemia, 7: 1824-1833.
35. Silver SM, McDonough MM, Vilaire G \& Bennett J S (1987). The in vitro synthesis of polypeptides for the platelet membrane glycoproteins IIb and IIIa. Blood, 69: 10311037.

36. Schonhorn J E, Akompong T \& WesslingResnick M (1995). Mechanism of transferrin receptor down regulation in $\mathrm{K} 562$ cells in response to protein kinase $\mathrm{C}$ activation. J ournal of Biological Chemistry, 270: 3698-3705.

37. Mehdi A, Bokhari SAJ , Yousuf N, Umerani A, Chughtai S, Hussain F \& Raza A (1992). A novel triple label method validates the double label technique of defining cell cycle kinetics in HL-60 cells. Anticancer Research, 12: 1443-1446.

38. Öberg F, Hult N, Bjare U, Ivhed I, Kivi S, Bregh J, Larsson L-G, Sundström C \& Nilsson K (1992). Characterization of a U937 subline which can be induced to differentiate in serum free medium. International J ournal of Cancer, 50: 153-160.

39. Yen A, Varvayanis S \& Platko J D (1993). 12-O-tetradecanoylphorbol-13-acetate and staurosporine induce increased retinoblastoma tumor suppressor gene expression with megakaryocytic differentiation of leukemic cells. Cancer Research, 53: 3085-3091.

40. Arbour NC, Prahl J M \& DeLuca HF (1993). Stabilization of the vitamin $D$ receptor in rat osteosarcoma cells through the action of 1,25-dihydroxyvitamin $D_{3}$. Molecular Endocrinology, 7: 1307-1312.

41. Hulla W, Kállay E, Krugluger W, Peterlik M \& Cross HS (1995). Growth control of human colon adenocarcinoma derived CACO-2 cells by vitamin D compounds and extracellular calcium in vitro: relation to c-myc oncogene and vitamin D receptor expression. International J ournal of Cancer, 62: 711-716.

42. Miyamoto K-I, Kesterson RA, Yamamoto $\mathrm{H}$, Taketani $\mathrm{Y}$, Nishiwaki E, Tatsumi S, Inoue $\mathrm{Y}, \mathrm{Morita} \mathrm{K}$, Takeda $\mathrm{E}$ \& Pike J W (1997). Structural organization of the human vitamin D receptor chromosomal gene and its promoter. Molecular Endocrinology, 11: 1165-1179.

43. Nishizuka $Y$ (1995). Protein kinase $C$ and lipid signaling sustained cellular responses. FASEB J ournal, 9: 484-496.

44. Escaleira MTF \& Brentani MM (1999). Vitamin $D_{3}$ receptor (VDR) expression in HC11 mammary cells: regulation by growth modulatory agents, differentiation and Ha-ras transformation. Breast Cancer Research and Treatment, 54: 123-134. 